Dikirim: 22 Desember 2015 Diterbitkan:1 September 2016

\section{Determinan kejadian tuberkulosis paru BTA (+) di kabupaten Bandung Barat}

\section{Determinants of pulmonary tuberculosis BTA (+) in the district of West Bandung}

Fitria Agustina ${ }^{1}$, Yusrizal Djam’an Saleh ${ }^{2}$, Hari Kusnanto ${ }^{1}$

\begin{abstract}
Purpose: This study aimed to determine the incidence of TB determination BTA (+) in the district of West Bandung. Methods: This research was an analytic observational study with a case control design. Subjects were patients aged 15 years and over who came to the clinic for treatment with a diagnosis of patients with TB BTA (+) as the case group, and patients who did not have TB diagnosis by an examining physician in the clinic as a control group. Samples included 140 people. Data analysis was performed by univariable, bivariable and multivariable analysis. Results: Income and education were significantly associated with the incidence of TB BTA (+), with p-value 0.040 and $0.037(p<0.05)$, respectively. Physical environment, smoking habits, the walls, the floor of the house, humidity, ventilation, lighting, cooking fuel, cigarette smoke exposure were significantly associated with the incidence of TB BTA $(+)(p$-value $<0.05)$. History of contact ( $p$-value $0.946>0.05$ ) and a history of BCG immunization ( $p$-value $0.611>0.05$ ) were not significantly associated with the incidence of TB BTA (+). Conclusion: Physical factors in the environment such as ventilation and fuel for cooking were significantly associated with the incidence of TB BTA (+). Appropriate efforts are recommended to avoid risks.
\end{abstract}

Keywords: determinants; pulmonary tuberculosis; BTA (+)

\footnotetext{
${ }^{1}$ Departemen Biostatistik, Epidemiologi dan Kesehatan Populasi, Fakultas Kedokteran Universitas Gadjah Mada (Email: fitri_ghania@yahoo.co.id)

${ }^{2}$ Rumah Sakit Dr. Sardjito Yogyakarta
} 


\section{PENDAHULUAN}

Tuberkulosis (TB) adalah penyakit menular langsung yang disebabkan oleh Mycobacterium tuberculosis. Penyakit menular Tuberkulosis masih menjadi perhatian dunia dan hingga saat ini, belum ada satu negara pun yang bebas TB. Angka kematian dan kesakitan akibat kuman TB pun tinggi, tahun 2009 sebesar 1,7 juta orang meninggal karena TB dan sepertiga dari populasi dunia sudah tertular dengan TB dimana sebagian besar penderita TB adalah kelompok usia produktif (15-55 tahun) (1). Sekitar 75\% pasien TB adalah kelompok usia yang paling produktif secara ekonomis, diperkirakan seorang pasien TB dewasa akan kehilangan rata-rata waktu kerjanya 3 sampai 4 bulan. Hal tersebut berakibat pada kehilangan pendapatan tahunan rumah tangga sekitar 20-30\%. Jika ia meninggal akibat $\mathrm{TB}$, maka akan kehilangan pendapatannya sekitar 15 tahun. Selain merugikan secara ekonomis, TB juga memberikan dampak buruk lainnya secara sosial yaitu stigma, bahkan dikucilkan oleh masyarakat(2).

World Health Organization (WHO) memperkirakan sepertiga (sekitar 2 milyar orang) dari populasi total dunia terinfeksi TB. Pada umumnya infeksi dipengaruhi oleh daya tahan tubuh dan hanya 10\% dari orang yang terinfeksi TB akan menjadi sakit dengan tanda dan gejala TB aktif di perjalanan hidupnya. Setiap tersangka TB merupakan faktor risiko penyakit TB jika tidak diobati dengan tepat dan setiap kasus TB aktif akan menginfeksi 10 hingga 15 orang setiap tahun(3). Keberhasilan pengobatan TB denganDirectly Observed Treatment Shortcourse (DOTS) tahun 2004 sebesar 83\% dan pada tahun 2005 meningkat hingga $91 \%$ (4). Indonesia merupakan negara pertama diantara negara - negara dengan beban tuberkulosis tinggi di wilayah Asia Tenggara yang berhasil mencapai target Global untuk tuberkulosis yaitu 70\% penemuan kasus baru TB BTA(+) (CDR) dan 85\% kesembuhan (5).

Situasi TB Global pada tahun 2006, diperkirakan terdapat kasus baru TB mencapai 9,2 juta dan 1,7 juta orang (25/100.000) meninggal karena TB, termasuk mereka yang juga memperoleh infeksi HIV (200.000) 4.

Menurut Global Tuberculosis Control Report tahun 2009, prevalensi tuberkulosis di Indonesia pada tahun 2007 sebesar 244 per 100.000 penduduk atau sekitar 565.614 kasus (semua kasus), insidensi kasus baru TB BTA (+) sebesar 102 per 100.000 penduduk atau sekitar 236.029 kasus baru TB BTA (+) sedangkan kematian karena TB sebesar 39 per 100.000 penduduk atau 250 orang per hari.
Penyebab utama meningkatnya beban masalah TB antara lain Kemiskinan pada berbagai kelompok masyarakat, seperti pada negara negara yang sedang berkembang; (Kegagalan program TB karena komitmen politik, pendanaan, dan organisasi pelayanan TB yang tidak memadai dikarenakan kurangnya akses oleh masyarakat, penemuan kasus/diagnosis yang tidak standar oleh petugas kesehatan, ketersediaan obat tidak terjamin, tidak dilakukan pemantauan, pencatatan dan pelaporan yang standar, dan sebagainya; Perubahan demografik karena meningkatnya penduduk dunia dan perubahan struktur umur kependudukan; Dampak pandemi infeksi HIV(3).

Beberapa faktor yang erat kaitannya dengan kejadian TB paru adalah adanya sumber penularan, riwayat kontak penderita, tingkat paparan, virulensi basil, daya tahan tubuh rendah terkait dengan genetik, keadaan gizi, faktor faali, usia, nutrisi, imunisasi, keadaan perumahan, pekerjaan dan tingkat sosial ekonomi(6).

Kabupaten Bandung Barat merupakan hasil pemekaran Kabupaten Bandung, Provinsi Jawa Barat, yang terdiri dari 15 kecamatan dan 165 desa. Penanggulangan tuberkulosis melalui strategi DOTS telah dilaksanakan di 31 puskesmas (7 Puskesmas Rujukan Mikroskopis, 7 Puskesmas Pelaksana Mandiri, dan 17 Puskesmas Satelit). Permasalahan penanggulangan TB di Kabupaten Bandung Barat adalah masih rendahnya angka penemuan penderita BTA (+) (CDR) yang belum mencapai target provinsi Jawa Barat yaitu 70\%. Pada tahun 2009 CDR sebesar $39,7 \%$, meningkat pada tahun 2010 sebesar 56,05\% kemudian capaian menurun lagi tahun 2011 menjadi $49,64 \%$. Mengacu pada rencana strategis kementerian kesehatan dari tahun 2010-2014, sasaran strategi nasional pengendalian TB yaitu menurunkan prevalensi TB dari 235 per 100.000 penduduk menjadi 224 per 100.000 penduduk. Sedangkan capaian prevalensi TB di KBB tahun 2009 adalah 265 per 100.000 penduduk, tahun 2010 yaitu 335 per 100.000 penduduk kemudian meningkat di tahun 2011 yaitu 517 per 100.000 penduduk.

Hasil pengawasan rumah sehat (Inspeksi Sanitasi Rumah Sehat) yang dilakukan di KBB tahun 2009 menghasilkan 25\% rumah sehat dari 14.931 rumah yang diperiksa. Kemudian, tahun 2010 meningkat menjadi 30,55\% rumah sehat dari 14.574 yang diperiksa. Faktor lingkungan yang tidak memenuhi syarat kesehatan merupakan faktor risiko sumber penularan berbagai jenis penyakit termasuk tuberkulosis paru. Masih besarnya persentase rumah 
tidak sehat ini merupakan masalah yang juga dihadapi oleh Kabupaten Bandung Barat.

Berdasarkan latar belakang diatas, terdapat beberapa permasalahan di Kabupaten Bandung Barat khususnya di tiga wilayah puskesmas yaitu Batujajar, Cimareme dan Pataruman, dimana kejadian TB masih tinggi dan pencapaian rumah sehat masih rendah. Dari berbagai permasalahan diatas maka penulis tertarik untuk melaksanakan penelitian tentang determinan kejadian TB Paru BTA (+) di Kabupaten Bandung Barat.

Tujuan Penelitian ini adalah untuk mengetahui determinasi kejadian TB paru BTA (+) di Kabupaten Bandung Barat dengan Menganalisis determinasi karakteristik individu terhadap kejadian TB paru BTA (+), lingkungan fisik, kontak penderita TB, riwayat imunisasi $\mathrm{BCG}$.

\section{METODE}

Jenis penelitian adalah penelitian observasional analitik dengan desain kasus kontrol dengan cara membandingkan kelompok kasus dan kelompok kontrol berdasarkan status paparannya. Variabel bebas (independent variables) adalah 1) karakteristik individu yang terdiri dari : pendidikan, pendapatan dan kebiasaan merokok, 2) lingkungan fisik rumah yang meliputi : jenis lantai, dinding rumah, kelembaban, ventilasi, pencahayaan, kepadatan hunian, bahan bakar untuk masak dan paparan asap rokok, 3) Kontak dengan penderita TB, 4) Riwayat imunisasi BCG. Variabel terikat (dependent variable) adalah kejadian TB Paru BTA (+).

Populasi dalam penelitian ini adalah seluruh masyarakat berusia 15 tahun keatas, yang datang berobat ke puskesmas Batujajar, Cimareme dan Pataruman dan melakukan pemeriksaan dahak (BTA). Kelompok Kasus adalah semua masyarakat berusia 15 tahun keatas yang datang berobat ke Puskesmas Batujajar, Cimareme dan Pataruman, melakukan pemeriksaan dahak ( BTA ) dan telah di diagnosis sebagai pasien TB BTA (+) baru oleh dokter pemeriksa di puskesmas. Kelompok Kontrol adalah semua masyarakat berusia 15 tahun keatas yang datang berobat ke Puskesmas Batujajar, Cimareme dan Pataruman; melakukan pemeriksaan dahak ( BTA ) dan telah di diagnosis bukan penderita TB oleh dokter pemeriksa di puskesmas.

Kriteria ekslusi kasus dan kontrol adalah pernah menderita TB sebelumnya ( BTA (+), BTA (-) atau Extra Paru), tetapi menolak / tidak bersedia menjadi responden atau alamat tidak ditemukan.
Sampel diambil menggunakan metode purposive sampling. Penelitian ini menggunakan perbandingan kasus dan kontrol 1 : 1, maka jumlah kasus dan kontrol secara keseluruhan berjumlah 140 sampel. Data yang sudah terkumpul dianalisis secara univariabel, bivariabel (chi square), multivariabel (regresi logistik)

\section{HASIL}

Responden kasus pada penelitian ini sebagian besar berusia 20-60 tahun sebanyak 54 (77,1\%) responden, sedangkan besar responden kontrol berusia 20-60 tahun sebanyak 63 (90,0\%) responden. Hal ini menunjukkan bahwa dari segi usia, responden di Kabupaten Bandung Barat sebagian besar adalah usia produktif.

Sebagian besar responden kasus berjenis kelamin laki-laki yaitu sebanyak $40 \quad(57,1 \%)$ responden, sedangkan responden kontrol sebagian besar berjenis kelamin perempuan yaitu sebanyak 44 (62,9\%) responden. Hal ini menunjukkan bahwa rata-rata jenis kelamin responden TB di Kabupaten Bandung Barat adalah kaum laki-laki. Mayoritas responden kasus berpendidikan tingkat tinggi yaitu sebanyak 36 (51,4\%) responden, sedangkan responden kontrol juga mayoritas berpendidikan tingkat tinggi yaitu sebanyak $49(70,0 \%)$ responden. Hal ini menunjukkan bahwa responden di Kabupaten Bandung Barat rata-rata memiliki pendidikan tingkat tinggi ( $\geq$ SLTP).

Sebagian besar responden bekerja sebagai karyawan swasta yaitu sebanyak 25 (35,7\%) responden, sedangkan responden kontrol sebagian besar bekerja sebagai IRT yaitu sebanyak 32 (45,7\%) responden. Hal ini menunjukkan bahwa dari segi pekerjaan responden TB di Kabupaten Bandung Barat sebagian besar bekerja pada bidang swasta. Sebagian besar responden kasus yang memiliki pendapatan < UMR sebanyak 46 (65,7\%) responden, sedangkan responden kontrol sebagian besar juga memiliki pendapatan < UMR yaitu sebanyak 37 (52,9\%) responden. Hal ini menunjukkan bahwa dari segi pendapatan responden $\mathrm{TB}$ di Kabupaten Bandung Barat sebagian besar memiliki pendapatan yang rendah (<UMR).

Faktor-faktor kejadian TB Paru BTA (+). Hasil analisis menunjukkan bahwa responden kasus sebagian besar tidak merokok yaitu sebanyak 39 (55,7\%), sedangkan sebagian besar responden kontrol juga tidak merokok yaitu sebanyak 52 (74,3\%). Sebagian besar responden kasus memiliki lantai rumah yang kedap air yaitu sebanyak 46 (65,7\%), sedangkan sebagian besar responden kontrol juga memiliki lantai 
rumah yang kedap air yaitu sebanyak 58 (82,9\%). Selain itu, mayoritas responden kasus memiliki rumah dengan dinding permanen sebanyak 51 (72,9\%), sedangkan sebagian besar responden kontrol juga memiliki rumah dengan dinding permanen sebanyak 62 (88,6\%). Sebagian besar rumah Responden kasus memiliki rumah dengan kelembapan kurang 40\% atau lebih dari 70\% sebanyak 45 (64,3\%), sedangkan sebagian besar responden kontrol juga memiliki rumah dengan kelembapan kurang 40\% atau lebih dari 70\% sebanyak 39 (55,7\%). Responden kasus sebagian besar memiliki rumah dengan lubang kurang dari 15\% luas lantai sebanyak 45 (64,3\%), sedangkan sebagian besar responden kontrol juga memiliki rumah dengan lubang ventilasi kurang dari 15\% luas lantai sebanyak 57 (81,4\%). Responden kasus sebagian besar memiliki rumah dengan pencahayaan kurang dari 60 lux sebanyak 65 (92,9\%), sedangkan responden kontrol sebagian besar juga memiliki rumah dengan pencahayaan kurang dari 60 lux sebanyak 56 (80,0\%). Responden kasus sebagian besar memiliki rumah dengan kepadatan hunian kurang dari $8 \mathrm{~m}^{2} /$ orang masing-masing sebanyak 35 (35,0\%), sedangkan sebagian besar responden kontrol juga memiliki rumah dengan kepadatan hunian kurang dari $8 \mathrm{~m}^{2} /$ orang sebanyak 41 (58,6\%). Responden kasus sebagian besar menggunakan bahan bakar minyak tanah/gas (kompor)/listrik untuk memasak sebanyak 67 (95,7\%), sedangkan responden kontrol sebagian besar juga menggunakan bahan bakar minyak tanah/gas (kompor)/listrik untuk memasak sebanyak 56 (80,0\%). Sebagian besar Responden kasus yang terkena paparan asap rokok sebanyak 40 (57,1\%), sedangkan responden kontrol sebagian besar tidak terkena paparan asap rokok yaitu sebanyak 43 (61,4\%). Responden kasus sebagian besar tidak memiliki riwayat kontak dengan penderita TB yaitu sebanyak 44 (62,9\%), sedangkan responden kontrol sebagian besar juga tidak memiliki riwayat kontak dengan penderita TB sebanyak 39 (55,7\%). Responden kasus sebagian besar memiliki riwayat imunisasi BCG sebanyak 36 (51,4\%), sedangkan responden kontrol sebagian besar juga memiliki riwayat imunisasi BCG sebanyak 40 (57,1\%).

Determinan Kejadian TB Paru BTA (+). Hasil analisis Chi Square menunjukkan bahwa pendapatan, pendidikan, kebiasaan, merokok dinding, lantai rumah, kelembapan, ventilasi, pencahayaan, bahan bakar masak, paparan asap rokok dengan kejadian TB Paru BTA (+) dengan OR antara 0,308-5,583. Lebih lanjut dapat dartikan, jika pendapatan, pendidikan, kebiasaan, merokok dinding, lantai rumah, kelembaban, ventilasi, pencahayaan, bahan bakar masak, paparan asap rokok semakin baik, maka kejadian TB Paru BTA (+) akan menurun. hubungan antara pendapatan, pendidikan, kebiasaan, merokok dinding, lantai rumah, kelembapan, ventilasi, pencahayaan, bahan bakar masak, paparan asap rokok dengan kejadian TB Paru BTA (+) di Puskesmas Kabupaten Bandung Barat memiliki keeratan yang rendah (coeficient contingency $<0,40$ )

Tabel 1. Odds ratio faktor risiko kejadian TB

\begin{tabular}{|c|c|c|c|c|}
\hline & \multicolumn{2}{|c|}{$\begin{array}{l}\text { Kejadian TB } \\
\text { Paru BTA }(+)\end{array}$} & \multirow[t]{2}{*}{ OR } & \multirow[t]{2}{*}{ CI 95\% } \\
\hline Pendapatan & $\mathrm{Ya}$ & Tidak & & \\
\hline$\geq \mathrm{UMR}^{-}$ & 24 & 37 & 0,465 & $0,236-0,919 *$ \\
\hline$<\mathrm{UMR}$ & 46 & 33 & & \\
\hline Pendidikan & Ya & Tidak & & \\
\hline Tinggi & 36 & 49 & 0,454 & $0,227-0,908^{*}$ \\
\hline Rendah & 34 & 21 & & \\
\hline Status Gizi & $\mathrm{Ya}$ & Tidak & & \\
\hline$\geq$ Normal & 61 & 58 & 1,402 & $0,550-3,576$ \\
\hline$<$ Normal & 9 & 12 & & \\
\hline $\begin{array}{l}\text { Kebiasaan } \\
\text { merokok }\end{array}$ & Ya & Tidak & & \\
\hline Tidak Merokok & 39 & 52 & 0,435 & $0,213-0,889^{*}$ \\
\hline Merokok & 31 & 18 & & \\
\hline Lantai Rumah & Ya & Tidak & & \\
\hline Kedap Air & 46 & 58 & 0,937 & $0,179-0,877^{*}$ \\
\hline Tidak Kedap Air & 24 & 12 & & \\
\hline Dinding & Ya & Tidak & & \\
\hline Memenuhi syarat & 51 & 62 & 0,346 & $0,140-0,856^{*}$ \\
\hline $\begin{array}{l}\text { Tidak memenuhi } \\
\text { syarat }\end{array}$ & 19 & 8 & & \\
\hline Kelembapan & Ya & Tidak & & \\
\hline Memenuhi syarat & 25 & 39 & 0,442 & $0,224-0,871^{*}$ \\
\hline $\begin{array}{l}\text { Tidak memenuhi } \\
\text { syarat }\end{array}$ & 45 & 31 & & \\
\hline Ventilasi & Ya & Tidak & & \\
\hline Memenuhi syarat & 25 & 13 & 2,436 & $1,121-5,292^{*}$ \\
\hline $\begin{array}{l}\text { Tidak memenuhi } \\
\text { syarat }\end{array}$ & 45 & 57 & & \\
\hline Pencahayaan & Ya & Tidak & & \\
\hline Memenuhi syarat & 5 & 14 & 0,308 & $0,104-0,908^{*}$ \\
\hline $\begin{array}{l}\text { Tidak memenuhi } \\
\text { syarat }\end{array}$ & 65 & 56 & & \\
\hline $\begin{array}{l}\text { Kepadatan } \\
\text { Hunian }\end{array}$ & $\mathrm{Ya}$ & Tidak & & \\
\hline Memenuhi syarat & 35 & 29 & 1,414 & $0,725-2,756$ \\
\hline $\begin{array}{l}\text { Tidak memenuhi } \\
\text { syarat }\end{array}$ & 35 & 41 & & \\
\hline $\begin{array}{l}\text { Bahan Bakar } \\
\text { Masak }\end{array}$ & Ya & Tidak & & \\
\hline $\begin{array}{l}\text { Minyak } \\
\text { tanah/Gas } \\
\text { (kompor)/listrik. }\end{array}$ & 67 & 56 & 5,583 & $1,527-20,415^{*}$ \\
\hline Kayu bakar & 3 & 14 & & \\
\hline $\begin{array}{l}\text { Paparan Asap } \\
\text { Rokok }\end{array}$ & Ya & Tidak & & \\
\hline Tidak & 30 & 43 & 0,471 & $0,240-0,925$ \\
\hline Ada & 40 & 27 & & \\
\hline Riwayat Kontak & $\mathrm{Ya}$ & Tidak & & \\
\hline Tidak & 44 & 39 & 1,345 & $0,684-2,646$ \\
\hline Ya & 26 & 31 & & \\
\hline $\begin{array}{l}\text { Riwayat } \\
\text { Imunisasi BCG }\end{array}$ & Ya & Tidak & & \\
\hline Ada Scar & 36 & 40 & 0,794 & $0,408-1,546$ \\
\hline
\end{tabular}

Selain itu, hasil analisis menunjukkan bahwa tidak ada hubungan yang bermakna antara kepadatan 
hunian, riwayat kontak, dan riwayat imunisasi BCG dengan kejadian TB Paru BTA (+) dengan OR antara 0,794-1,414.

Determinan Multivariat Kejadian TB Paru BTA(+). Analisis Regresi Logistik menghasilkan $p$ value untuk variabel kelembapan, kepadatan hunian dan bahan bakar untuk memasak $=0,000,0,002$, dan 0,049 dan dengan tingkat signifikansi $(\alpha)=5 \%$. Oleh karena $p$ value $=0,000,0,002$, dan $0,049<0,05$, variabel kelembapan, kepadatan hunian, dan bahan bakar berpengaruh signifikan terhadap kejadian TB Paru BTA $(+)$.

\section{BAHASAN}

Sepertiga dari populasi dunia sudah tertular dengan TB dimana sebagian besar penderita TB adalah usia produktif (15-55 tahun) (1). Sekitar 75\% pasien TB adalah kelompok usia yang paling produktif secara ekonomis dan diperkirakan seorang pasien TB dewasa akan kehilangan rata-rata waktu kerjanya 3 sampai 4 bulan. Hal ini berakibat pada kehilangan pendapatan tahunan rumah tangganya sekitar 20-30\%. Jikas seseorang meninggal akibat TB, maka akan kehilangan pendapatan sekitar 15 tahun. Selain merugikan secara ekonomis, TB juga memberikan dampak buruk secara sosial yaitu stigma, bahkan dikucilkan oleh masyarakat(2).

Hasil penelitian ini didukung oleh Rusnoto, et al., yang melakukan penelitian tentang "Faktor-faktor yang Berhubungan Dengan Kejadian Tb Paru pada Usia Dewasa (Studi kasus di Balai Pencegahan dan Pengobatan Penyakit Paru Pati)", dimana hasil penelitiannya menunjukkan bahwa kelompok usia yang terkena TB adalah usia produktif dan variabel lingkungannya juga cukup baik(7). Hasil penelitian ini juga didukung oleh Leinhardt, et al. yang melakukan penelitian tentang " Investigation of the risk factor for tuberkulosis : a case-control study in three countries in West Africa”, dimana hasil penelitiannya menunjukkan bahwa faktor lingkungannya kurang baik(8).

Hasil penelitian ini juga didukung oleh Tobing yang melakukan penelitian tentang "Pengaruh Perilaku Penderita TB Paru dan Kondisi Rumah terhadap Pencegahan Potensi Penularan TB Paru Pada Keluarga di Kabupaten Tapanuli Utara Tahun 2008", dimana hasil penelitiannya menunjukkan bahwa kepadatan hunian yang padat, ventilasi juga cukup baik,dan pencahayaan juga cukup baik (9). Hasil penelitian ini juga didukung oleh Fatimah yang melakukan penelitian tentang "Faktor Kesehatan Lingkungan
Rumah yang Berhubungan dengan Kejadian Tb Paru di Kabupaten Cilacap (Kecamatan : Sidareja, Cipari, Kedungreja, Patimuan, Gandrungmangu, Bantarsari) Tahun 2008", dimana hasil penelitiannya menunjukkan bahwa lingkungan fisik rumah di Kecamatan : Sidareja, Cipari, Kedungreja, Patimuan, Gandrungmangu, Bantarsari juga cukup baik (10).

Penyebab utama meningkatnya beban masalah TB antara lain (1). Kemiskinan pada berbagai kelompok masyarakat, seperti pada negara negara berkembang; (2). Kegagalan program TB diakibatkan oleh komitmen politik pendanaan, organisasi pelayanan TB yang tidak memadai dikarenakan kurangnya akses masyarakat, penemuan kasus/diagnosis yang tidak standar oleh petugas kesehatan, ketersediaan obat tidak terjamin, tidak dilakukan pemantauan, pencatatan dan pelaporan yang standar, dan sebagainya; (3) Perubahan demografik karena meningkatnya penduduk dunia dan perubahan struktur umur kependudukan; (4). Dampak pandemi infeksi HIV(2).

Determinan Kejadian TB Paru BTA (+). Hasil uji Chi Square pada penelitian ini didukung oleh Rusnoto, et al., menunjukkan bahwa kelompok umur dan variabel lingkungan berhubungan dengan Kejadian $\mathrm{Tb}$ Paru pada Usia Dewasa di Balai Pencegahan dan Pengobatan Penyakit Paru Pati(7). Hasil penelitian ini juga didukung oleh Tobing yang melakukan penelitian tentang "Pengaruh Perilaku Penderita TB Paru dan Kondisi Rumah terhadap Pencegahan Potensi Penularan TB Paru Pada Keluarga di Kabupaten Tapanuli Utara Tahun 2008", dimana hasil penelitian menunjukkan bahwa kepadatan hunian, ventilasi, pencahayaan berhubungan dengan Potensi Penularan TB Paru Pada Keluarga di Kabupaten Tapanuli Utara(9). Hasil penelitian ini juga didukung oleh Fatimah yang melakukan penelitian tentang "Faktor Kesehatan Lingkungan Rumah yang Berhubungan dengan Kejadian $\mathrm{Tb}$ Paru di Kabupaten Cilacap (Kecamatan : Sidareja, Cipari, Kedungreja, Patimuan, Gandrung- mangu, Bantarsari) Tahun 2008”, dimana hasil penelitian menunjukkan bahwa lingkungan fisik rumah berhubungan dengan Kejadian Tb Paru Di Kabupaten Cilacap (Kecamatan : Sidareja, Cipari, Kedungreja, Patimuan, Gandrungmangu, Bantarsari) Tahun 2008 (10).

Beberapa faktor yang memiliki kaitan yang erat dengan kejadian TB paru adalah adanya sumber penularan, riwayat kontak penderita, tingkat paparan, virulensi basil, daya tahan tubuh rendah berkaitan dengan genetik, keadaan gizi, faktor faali, usia, nutrisi, imunisasi, keadaan perumahan, pekerjaan dan tingkat 
sosial ekonomi(6). Tingkat pendidikan seseorang akan mempengaruhi pengetahuan seseorang mengenai rumah yang memenuhi syarat kesehatan dan pengetahuan penyakit TB paru, sehingga dengan pengetahuan yang cukup maka seseorang akan mencoba untuk mempunyai perilaku hidup bersih dan sehat.

Keterbatasan kesempatan untuk memperoleh pendidikan merupakan faktor yang dapat memengaruhi tingkat kesehatan serta upaya pencegahan penyakit. Dalam kelompok masyarakat dengan tingkat pendidikan yang rendah, pada umumnya memiliki status ekonomi yang rendah pula. Mereka sulit menyerap informasi kesehatan mengenai penularan dan cara pencegahannya. Pendidikan yang rendah menyebabkan masyarakat tidak tahu cara untuk memilih makanan yang bergizi dan pengadaan sarana sanitasi yang diperlukan(11).

Sanitasi rumah merupakan usaha kesehatan masyarakat yang menitikberatkan kepada pengawasan terhadap berbagai faktor lingkungan di dalam maupun di luar rumah yang dapat memengaruhi derajat kesehatan masyarakat dengan timbulnya atau penularan penyakit. Pengawasan lingkungan meliputi pengawasan lingkungan fisik, biologi, sosial dan ekonomi yang memengaruhi kesehatan manusia. WHO membuktikan pentingnya lingkungan rumah melalui observasi yang dilakukan di seluruh dunia dimana didapatkan angka kematian, perbandingan orang sakit yang tinggi sering menjadi epidemi, tempat-tempat hygiene dan sanitasi lingkungan buruk antara lain tempat yang banyak terdapat lalat, nyamuk, pembuangan kotoran dan sampah sembarangan, kualitas air rumah tangga yang buruk, perumahan yang terlalu padat serta kondisi sosial ekonomi yang jelek. Apabila hygiene dan sanitasi lingkungan diperbaiki maka mortalitas dan morbiditas akan menurun, sedangkan wabah akan berkurang dengan sendirinya.

Menurut Sanroepi et.al. selain sebagai penyangga atau pendukung atap, dinding berfungsi untuk melindungi dari pengaruh panas. Kelembapan di dalam rumah berkisar antara $40-70 \%$ dan suhu ruang ideal antara $18-30^{\circ} \mathrm{C}$. Oleh karena itu, perlu diperhatikan kelembaban di dalam rumah karena akan memengaruhi berkembangbiaknya mikroorganisme termasuk Mycobacterium tuberculosis (12). Menurut Dinas Pekerjaan Umum, kelembapan di dalam rumah dapat disebabkan karena kelembapan yang naik dari tanah dan merembes dari dinding (13). Kelembapan yang terlalu tinggi dapat menyebabkan lantai dan dinding selalu basah, sehingga lantai perlu dibuat dari bahan yang kedap air seperti semen, tegel, keramik ataupun marmer(14). Pada batas-batas suhu atau temperatur tertentu mikroorganisme dapat bertahan, dimana batas-batas itu adalah temperatur minimum dan maksimum, sedangkan temperatur yang paling baik bagi kegiatan hidup adalah temperatur optimum. Mycobacterium tuberculosis akan tumbuh dengan optimal pada suhu $37^{\circ} \mathrm{C}(15)$.

Selain sebagai tempat keluar masuknya udara, jendela juga berfungsi sebagai lubang pencahayaan dari luar dan cahaya matahari mempunyai daya untuk membunuh bakteri sehingga jendela penting bagi sebuah rumah. Di daerah pedesaan, banyak rumah penduduk yang tidak dilengkapi dengan jendela atau ada tapi tidak membuka jendela rumahnya. Hal inilah yang dapat menimbulkan udara yang pengap karena tidak ada pergantian udara kotor dengan udara bersih. Tidak tersedianya ventilasi yang baik pada suatu ruangan akan membahayakan kesehatan atau kehidupan (16). Faktor terbesar yang dapat menurunkan kasus tuberkulosis berhubungan erat dengan meningkatnya sosial ekonomi. Namun, Tidak diketahui dengan pasti komponen sosial ekonomi apa saja yang menjadi faktor penentu tetapi yang jelas penularan terjadi hampir di semua lingkungan yang tertutup. Perbaikan-perbaikan perumahan dengan ventilasi yang baik dan mengurangi kepadatan hunian merupakan suatu perubahan yang penting, demikian juga pada perbaikan status gizi (17).

Masyarakat dengan status ekonomi rendah sering mengalami kesulitan mendapatkan pelayanan kesehatan yang baik. Kelompok masyarakat ini akan terjebak pada rutinitas mencari nafkah untuk mempertahankan hidupnya tanpa mempedulikan kualitas hidupnya. Perumahan dan sanitasi serta cara hidup yang sehat belum menjadi perhatian mereka. Keadaan ekonomi yang rendah sering memaksa mereka hidup di daerah kumuh atau daerah prostitusi. Dengan keadaan seperti ini, penyakit tuberkulosis paru akan menjadi ancaman bagi mereka (11). Merokok mempunyai hubungan dengan meningkatnya risiko kanker paru, penyakit jantung koroner, bronkitis kronik dan kanker kandung kemih. Kebiasaan merokok meningkatkan risiko untuk terkena TB paru sebanyak 2,2 kali. Pajanan asap rokok juga dapat dialami oleh orang yang tidak mempunyai kebiasaan merokok (perokok pasif).

Hasil analisis menunjukkan bahwa tidak ada hubungan yang bermakna antara kepadatan hunian, riwayat kontak, dan riwayat imunisasi BCG dengan kejadian TB Paru BTA (+). Lebih lanjut dapat diartikan, jika kepadatan hunian, riwayat kontak, dan riwayat imunisasi BCG semakin baik, maka kejadian TB Paru BTA (+) akan tetap atau konstan. Hal ini kemungkinan disebabkan karena sebagian besar kelompok kasus 
maupun kelompok kontrol pada kategori status gizi yang baik. status gizi merupakan faktor risiko kejadian tuberkulosis paru. Penularan TB paru dapat terjadi pada kontak dengan penderita seperti pada penelitian Topley yang membuktikan bahwa 63,8\% (180 anak) yang terdeteksi menderita TB paru berasal dari kontak serumah dengan keluarga atau orang tua yang menderita TB paru melalui skrining klinis (18). Vaksin BCG merupakan vaksin yang paling aman dan sangat reaktogenik diantara vaksin yang ada saat ini (19). Reaksi yang sering ditemukan adalah ulkus lokal dan limfadenitis regional. Ulkus lokal yang superfisial terjadi 3 minggu setelah penyuntikan yang biasanya ditutupi krusta dan akan sembuh dalam 2-3 bulan(19, 20).

Imunisasi BCG merupakan salah satu upaya pengendalian infeksi tuberkulosis selain kemoprofilaksis dan penemuan serta pengobatan kasus dengan metoda DOTS $(21,22)$. Imunisasi BCG tidak mencegah infeksi TB, tetapi mengurangi risiko TB berat seperti meningitis TB atau TB miliar (19, 20). Efek proteksi ini timbul 8-12 minggu setelah penyuntikan (20). Efektifitas BCG untuk mencegah TB primer bervariasi antara $0-80 \%(23)$.

\section{Determinan Multivariat Kejadian TB Paru} BTA(+). Hasil analisis regresi logistik pada penelitian ini didukung oleh Rusnoto, et al., dengan hasil penelitian yang menunjukkan bahwa lingkungan berhubungan dengan Kejadian Tb Paru pada Usia Dewasa di Balai Pencegahan dan Pengobatan Penyakit Paru Pati (7). Hasil penelitian ini juga didukung oleh Tobing yang melakukan penelitian tentang "Pengaruh Perilaku Penderita TB Paru dan Kondisi Rumah terhadap Pencegahan Potensi Penularan TB Paru Pada Keluarga di Kabupaten Tapanuli Utara Tahun 2008”, dimana hasil penelitiannya menunjukkan bahwa kepadatan hunian, ventilasi, pencahayaan berhubungan dengan Potensi Penularan TB Paru Pada Keluarga di Kabupaten Tapanuli Utara (9).

\section{SIMPULAN}

Karakteristik individu pendapatan dan pendidikan, lingkungan fisik kebiasaan merokok, dinding, lantai rumah, kelembapan, ventilasi, pencahayaan, bahan bakar masak, paparan asap rokok berhubungan signifikan dengan TB Paru BTA (+). Riwayat kontak dan riwayat imunisasi BCG tidak berhubungan dengan kejadian TB Paru BTA (+). Variabel ventilasi dan bahan bakar untuk memasak berhubungan signifikan dengan kejadian TB Paru BTA (+).

\section{Abstrak}

Tujuan: Penelitian ini bertujuan mengetahui determinasi kejadian TB Paru BTA (+) di Kabupaten Bandung Barat. Metode: Jenis penelitian adalah observasional analitik dengan desain kasus kontrol. Subjek penelitian adalah masyarakat 15 tahun keatas datang berobat ke puskesmas dan diagnosis pasien TB BTA (+) sebagai kelompok kasus, serta pasien yang diagnosis bukan penderita TB oleh dokter pemeriksa di puskesmas sebagai kelompok kontrol. Sampel yang diambil sebanyak 140 orang. Analisis data dilakukan dengan analisis univariabel, bivariabel dan multivariabel. Hasil: Karakteristik individu pendapatan dan pendidikan berhubungan signifikan dengan kejadian TB Paru BTA (+). Lingkungan fisik, kebiasaan merokok, dinding, lantai rumah, kelembapan, ventilasi, pencahayaan, bahan bakar masak, paparan asap rokok berhubungan signifikan dengan kejadian TB Paru BTA (+). Riwayat kontak dan riwayat imunisasi BCG tidak berhubungan signifikan dengan kejadian TB Paru BTA (+). Simpulan: Ventilasi dan bahan bakar untuk memasak berhubungan signifikan dengan kejadian TB Paru BTA (+).

Kata kunci: determinan; tuberkulosis paru; BTA (+)

\section{PUSTAKA}

1. Kementerian Kesehatan. Indonesia Peringkat 5 Dunia Penderita TB terbanyak. 2011.

2. Kementerian Kesehatan. Pedoman Nasional Penanggulangan Tuberkulosis. Jakarta : Dirjen PP dan PL. 2011.

3. World Health Organization. WHO Report 2009 : Global Tuberculosis Control Epidemiology Strategy. Geneva : WHO Press. 2009.

4. Departemen Kesehatan RI dan WHO. Hari TB se-dunia 24 Maret 2008. Jakarta : Sub Direktorat TB Depkes RI. 2008.

5. Kementerian Kesehatan RI. Rencana Aksi Nasional Informasi Strategis Pengendalian Tuberkulosis Indonesia : 2011-2014. Jakarta : Direktorat Jendral Pengendalian Penyakit Dan Penyehatan Lingkungan. 2011.

6. Amin, Alsegaf, H. Pengantar Penyakit Paru. Surabaya : Air Langga University Press. 1989.

7. Rusnoto, Rahmatullah P, Udiono A. Faktor-Faktor yang Berhubungan dengan Kejadian TB Paru pada Usia Dewasa (Studi Kasus di Balai Pencegahan dan Pengobatan Penyakit Paru Pati). Artikel Publikasi Tesis, Universitas Diponegoro. 2006.

8. Lienhardt C, Fielding K, Sillah JS, Bah B, Gustafson P, Warndorff D, Palayew M, Lisse I, Donkor S, Diallo S, Manneh K. Investigation of the risk factors for tuberculosis: a case-control study in three countries in West Africa. International journal of epidemiology. 2005 May 24;34(4):914-23.

9. Tobing TL. Pengaruh Perilaku Penderita TB Paru dan Kondisi Rumah Terhadap Pencegahan Potensi 
Penularan TB Paru pada Keluarga di Kabupaten Tapanuli Utara Tahun 2008. Thesis, Universitas Sumatera Utara. 2009.

10. Fatimah, S. Faktor Kesehatan Lingkungan Rumah yang Berhubungan dengan Kejadian TB Paru di Kabupaten Cilacap (Kecamatan: Sidareja, Cipari, Kedungreja, Patimuan, Gandrungmangu, Bantarsari) Tahun 2008. Tesis, Universitas Diponegoro. 2008.

11. Soewasti SS, Sudomo S, Wahyu I. Aspek-aspek Ekologi dan Sosial dalam Penanggulangan "Emerging Infection Diseases" Buletin Penelitian Kesehatan, Badan Penelitian dan Pengembangan Kesehatan. 1997 ; 25 (2 \& 3) : 61-67.

12. Sanroepi D, Gunarso IT, Adisapto W, Gandasasmita U, Soemini, Sidik I, Debatradja M, Suyanto, Wijoyono U, Santoso, Winarko, Sukini E, Marlina N, Kusumawati S, Soingkilawang J. Pengawasan Penyehatan Pemukiman. Jakarta : Pusat Pendidikan Tenaga Kesehatan, Departemen Kesehatan RI. 1989.

13. Departemen Pekerjaan Umum RI. Rumah dan Lingkungan Pemukiman Sehat. Jakarta: Ditjen Cipta Karya. 1997.

14. Lubis P. Perumahan Sehat. Jakarta : Pusat Pendidikan Tenaga Kesehatan, Departemen Kesehatan RI. 1989.

15. Mariono S. Resistensi Kuman Tuberkulosis. Majalah Penyuluh (PPTI). Edisi ke-9. Jakarta: 15. 1989.

16. Azwar, A. Pengantar Ilmu Kesehatan Lingkungan. Jakarta : 27-98 : Mutiara Sumber Widya. 1995.
17. Smith PG, Moss AR. Epidemiology of Tuberculosis, Tuberculosis Pathogenesis, Protection and Control. ASM Press; Washington DC : 47-51. 1994.

18. Topley JM, Maher D, Mbewe LN. Transmission of tuberculosis to contacts of sputum positive adults in Malawi. Archives of disease in childhood. 1996 Feb 1;74(2):140-3.

19. Fine PE, Carneiro IA, Milstien JB, Clements CJ, World Health Organization. Issues relating to the use of BCG in immunization programmes: a discussion document.

20. Supriyo S, Baequny A, Hidayati S, Hartono M, Harnany AS. Pengaruh Perilaku dan Status Gizi terhadap Kejadian TB Paru Di Kota Pekalongan. Pena Medika Jurnal Kesehatan. 2013;4(1).

21. Rahayu NN. Tuberkulosis. Dalam: Ranuh IGN, Suyitno, Hadinegoro SRS, Kartasasmita C, penyunting. Buku imunisasi di Indonesia. Edisi ke-1. Jakarta:Satgas Imunisasi - IDAI;h.79-82. 2001.

22. Inselman LS, Kendig EL. Tuberculosis. Dalam: Chernick V, Kendig EL, penyunting. Kendig's Disorders of The Respiratory Tract in Children. Edisi ke-5. Philadelphia: Saunders; h.760-6. 1990.

23. Putrali J, Sutrisna B, Rahayu N, Gunardi AS. Gunowiseso. Penelitian efektifitas vaksinasi BCG pada anak-anak di 8 rumah sakit di Jakarta. Medika. 1982;10:779-82.

24. Fine PE. Variation in protection by BCG: implications of and for heterologous immunity. The Lancet. 1995 Nov 18;346(8986):1339-45. 